УДК 94 (477) “1918-1919”

\title{
СТАНОВЛЕННЯ ДИПЛОМАТИЧНОЇ СЛУЖБИ ЗУНР (осінь 1918 - весна 1919 рр.)
}

\author{
Любомира ФЕДУНИШИН \\ Бурштинський енергетичний коледж \\ Івано-Франківського національного технічного університету нафти і газу, \\ вул. Калуська 4, 77111, Бурштин, Украӥна \\ e-mail: fedunyshyn3@gmail.com \\ DOI: $10.15330 /$ gal.32.55-66 \\ ORCID: 0000-0001-8629-5476
}

У статті досліджено процес становлення дипломатичної служби Західно-Української Народної Республіки (ЗУНР), особливості і проблеми діяльності міжнародних представництв і місій. Зазначено, шзо важливим завданням було формування зовнішньополітичного апарату і визначення пріоритетів зовнішньої політики: об'єднання з Українською Народною Республікою (УНР), здобуття прихильності краӥн Антанти, налагодження відносин з Чехо-Словацькою республікою, Угорщиною, Румунією та іншими краӥнами з метою збереження незалежності, територіальної иілісності $і$ здобуття міжнародного визнання. Автором висвітлено про відкриття представництв і посольств у Відні, Празі, Будапешті, Бухаресті, Лондоні, Берліні, Вінніпегу, Оттаві, Вашингтоні та інших містах.

Ключові слова: Західно-Украӥнська Народна Республіка, дипломатична служба, закордонна місія, представництво, міжнародна діяльність, посол, делегація, зовнішня політика.

Сьогодні, коли незалежна Україна продовжує формувати свою зовнішньополітичну доктрину, зростає інтерес до всебічного вивчення діяльності міжнародних представництв ЗУНР як українського державного утворення в Східній Галичині. У зв'язку з цим, актуальним завданням української історичної науки є об'єктивно оцінити та врахувати здобутки і прорахунки становлення дипломатичної служби ЗУНР, взяти до уваги позитивні і негативні фактори діяльності галицької республіки, яка опинилася на перехресті геостратегічних інтересів великих держав у Центрально-Східній Європі. Сьогодні, як і 100 років тому, на міжнародні представництва покладається велика відповідальність за реалізацію і частково формування зовнішньої політики держави. Адже від професійної й послідовної реалізації стратегічно правильно обраного зовнішньополітичного курсу, кадрового складу дипломатичної служби, форм і методів іїі роботи залежить доля країни.

В українській історіографії різні аспекти зовнішньої політики ЗУНР досліджували В. Ададуров, Д. Веденєєв, С. Віднянський, Л. Гентош, О. Герус, Ю. Довган, Я. Калакура, О. Карпенко, В. Кройтор, О. Кучик, М. Литвин, М. Нагорняк, К. Науменко, О. Павлишин, О. Павлюк, А. Панчук, Б. Тищик та інші. Спеціальним проблемам історії ЗУНР присвячені праці прикарпатських вчених В. Великочого, Т. Галицької-Дідух, Л. Дрогомирецької, О. Жерноклеєва, М. Кугутяка, І. Райківського, Л. Шологон та інших. Основними тенденціями в сучасній історіографії $є$ активне освоєння іноземних документів, повернення матеріалів із закордонних архівів, спроби їх інтерпретації, порівняльного аналізу, критики та введення до наукового обігу.

Метою даної статті є висвітлення процесу становлення дипломатичної служби ЗУНР, з'ясування особливостей і проблем діяльності міжнародних представництв та місій, оскільки заявлена тема потребує окремого вивчення.

Одним із головних завдань, які постали наприкінці 1918 р. перед новоутвореною Західно-Українською Народною Республікою, було формування зовнішньої політики, визначення iii пріоритетів, утворення відповідного політичного апарату. 3 початку свого існування територія ЗУНР стала об'єктом зазіхань і військової агресії з боку сусідніх країн. Галицьке керівництво опинилося у фактичній міжнародній ізоляції. Однобока орієнтація на Австро-Угор- 
56

щину і Німеччину під час Першої світової війни означала цілковиту відсутність зв’язків 3 урядами держав Антанти і США.

Зовнішньополітичні заходи ЗУНР були спрямовані на активну дипломатичну діяльність 3 метою звільнити території від польського агресора і здобути визнання інших держав. Їх втілення у життя покладалося у сформованому 9 листопада 1918 р. в м. Львові уряді - Державному Секретаріаті - на посаду держсекретаря закордонних справ, яку обійняв член національно-демократичної партії Василь Панейко ${ }^{1}$. Заступником В. Панейка став націоналдемократ Л. Цегельський, який з січня 1919 р., після від’їзду держсекретаря на Паризьку мирну конференцію, фактично керував роботою галицької дипломатії до 12 лютого 1919 р., коли ці функції перебрав С. Витвицький. У середині березня 1919 р. головою відомства став М. Лозинський, який зумів дістатися до Станиславова з окупованого поляками Львова.

Було розпочато формування дипломатично-консульських взаємин. Одним із перших відкрито представництво у Києві (діяло до 22 січня 1919 р.) $)^{2}$. Уряд ЗУНР одним із перших завдань поставив об'єднання з Наддніпрянською Україною в єдиній, соборній, самостійній державі і велися переговори з урядами УНР.

Представники галицьких соціал-демократів на чолі з М. Ганкевичем рішуче виступили за негайну злуку. Ця ідея мала багато прихильників, особливо серед студентства і українських січових стрільців. Проте члени національно-демократичної і радикальної партії, яким належала перевага в Українській Національній Раді (УНРаді), виступали на даному етапі за збереження федеративного зв'язку 3 новою Австрією ${ }^{3}$. Згодом це стало причиною для звинувачення УНРади й, зокрема, іiі президента $Є$. Петрушевича в австрофільській політиці та небажанні об'єднання всіх українських земель.

Офіційні взаємини західноукраїнського політичного проводу з керівництвом Наддніпрянщини розпочалися за правління П. Скоропадського. 29 жовтня 1918 р. представник О. Колесса повідомив гетьманові та Міністерству закордонних справ Української держави про створення УНРади як конституанти українських земель Австро-Угорщини. 5 листопада 1918 p. за дорученням командування галицько-українських збройних сил 3 проханням про військову допомогу до української столиці вирушив Осип Назарук ${ }^{4}$.

10 листопада 1918 р. УНРада прийняла ухвалу, в якій доручила урядові “поробити потрібні заходи для з'єдинення всіх українських земель в одну державу" ". Здійснення практичних кроків для об'єднання було доручено урядовцеві австро-угорського посольства у Києві Григорію Микитею. Критичний момент у спробі налагодження взаємовідносин настав після проголошення П. Скоропадським Акту про федеративний зв'язок Української Держави з Росією. Такий крок гетьмана спонукав Г. Микитея утриматися від посольської акредитації, адже злука з гетьманської Україною загрожувала Східній Галичині опинитися в складі єдиної Росії.

Після встановлення в УНР влади Директорії на чолі з лідером УСДРП В. Винниченком, уряд ЗУНР відсилає делегацію у складі д-ра Льонгина Цегельського і д-ра Дмитра Левицького, яка 1 грудня 1918 р. підписала "Передвступний договір, заключний у м. Фастові між Українською Народною Республікою і Західно-Українською Народною Республікою про маючу наступити злуку обох українських держав в одну державну одиницю”. Це був прелімінарний договір - перший офіційний документ щодо Злуки, в якому зазначалося, що ЗУНР “заявляє свій

\footnotetext{
1 Західно-Українська Народна Республіка 1918-1923. Документи і матеріали : у 5 т. Т. 1 : Листопадова 1918 р. національно-демократична революція. Проголошення ЗУНР / укладачі О. Карпенко, К. Мицан. Івано-Франківськ : Лілея-НВ, 2001. С. 23.

2 Литвин М., Науменко К. Історія ЗУНР. Львів : Інститут українознавства НАН України, 1995. С. 122.

${ }^{3}$ Павлюк О. Зовнішня політика ЗУНР. Всесвіт. 1992. № 1-2. С. 176.

${ }^{4}$ Павлишин О. Об’єднання УНР і ЗУНР: політико-правовий аспект (кінець 1918 р. - перша половина 1919 р.). Вісник Львівського університету. Історія. 2002. Вип. 37/1. С. 329.

${ }^{5}$ Карпенко О. Основні напрями зовнішньої політики Західно-Української Народної Республіки. Україна : культурна спадщина, національна свідомість, державність. Західно-Українська Народна Республіка. Львів, 2000. Вип. 6. С. 230.
} 
намір перестати існувати як окрема держава, а натомість увійти з усією територією й населенням, як складова частина державної цілости, в Українську Народну Республіку”б.

3 січня 1919 р. перша сесія УНРади у Станіславові одноголосно прийняла ухвалу про затвердження тексту договору від 1 грудня 1918 р.7. Для завершення процесу об'єднання до Києва виїхала західноукраїнська делегація у складі 65 чол. під проводом заступника голови УНРади Л. Бачинського. 21 січня 1919 р. відбулася нарада делегації ЗУНР з урядом УНР, де був оголошений прийнятий Директорією Універсал про об'єднання. 22 січня на Софіївській площі відбулося урочисте проголошення Акту Злуки українських земель, де говорилося: “Віднині воєдино зливаються століттями відірвані одна від одної частини єдиної України, ЗахідноУкраїнська Народна Республіка (Галичина, Буковина і Угорська Русь) і Наддніпрянська Велика Україна"8.

23 січня 1919 р. на Трудовому Конгресі України Акт Злуки було затверджено. ЗУНР перетворилася в Західну область УНР (ЗОУНР) на основі федеративного принципу ${ }^{9}$. Об'єднання українських земель відбулося в юридичному та політичному відношеннях. Проте фактичного державного об'єднання здійснено не було. Надто різними були зовнішньополітичні завдання обох українських держав. Директорія бачила головну загрозу для себе з боку радянської і білої Росії, а Державний Секретаріат протистояв імперіалістичним домаганням Польщі. Та попри всі незгоди урядів двох республік, Акт злуки 22 січня 1919 р. був досить вагомим на той час здобутком діяльності галицької дипломатії, зокрема в загальнонаціональному вимірі українців ${ }^{10}$.

Складна міжнародна ситуація поставила під загрозу існування і ЗУНР і УНР: із заходу вчинила агресію Польща, з півночі - радянська Росія. Це спонукало ЗУНР до прагнення здобути визнання інших держав. У листопаді - грудні 1918 р. відкрито дипломатичні представництва ЗУНР у Відні, Берліні, Будапешті, Празі. Відень взагалі став центром всієї міжнародної діяльності ЗУНР, своєрідним містком, що зв'язував Станіславів з осередком європейської політики. Це пояснювалося як історичною традицією, пов'язано з участю українців у роботі австрійського парламенту, так і відносно прихильним ставленням офіційного Відня до ЗУНР. Австрійський уряд був єдиним, хто визнав легітимність представників ЗУНР на своїй території. Крім того, українські делегати брали участь у роботі Ліквідаційної комісії, утвореної у Відні для розподілу активів і майна колишньої Австро-Угорщини. Так, Є. Петрушевич майже на два місяці затримався у Відні і повернувся до Галичини лише наприкінці грудня. "Треба було зорганізувати поворот українського вояцтва з італійського та балканського фронтів, полагодити справу участі західно-української держави в ліквідації майна австро-угорської монархії, нав'язати зв'язки з західним світом та зорієнтуватися в тенденціях політики переможних держав" ${ }^{\prime 1}$.

Послом в Австрію був призначений М. Василько, який тривалий час був депутатом австрійського парламенту й мав сильні позиції серед місцевих владних еліт. Очолюване ним посольство стало одним 3 найактивніших у дипломатичній службі ЗУНР - 30 УНР, і його досягнення значно виходили за межі двосторонніх відносин. Так, у Відні під егідою посольства ЗУНР діяла Українська пресова служба (УПС) ${ }^{12}$. За Д. Веденєєвим, Українське пресове бюро

\footnotetext{
${ }^{6}$ Конституційні акти України 1917-1920: Невідомі конституції України. Київ : Філос. і соціол. думка, 1996. С. 108.

7 Західно-Українська Народна Республіка 1918-1923. Документи і матеріали : у 5 т. Т. 2 : Державотворчі й адміністративно-організаційні процеси / укладачі О. Карпенко, К. Мицан. Івано-Франківськ : Лілея-НВ, 2003. C. 142.

${ }^{8}$ Україна в XX столітті : збірник документів і матеріалів. Київ : Вища школа, 2000. С. 68.

${ }^{9}$ Калакура Я., Панчук А. Новітня історіографія Злуки УНР та ЗУНР. Украӥнська соборність : ідея, досвід, проблеми (До 80-річчя Акту злуки 22 січня 1919 р.) : збірник. Київ : ІПіЕНД, 1999. С. 238.

${ }^{10}$ Веденєєв Д. Українська історіографія про причини та наслідки розриву Акту Злуки (зовнішньополітичний аспект). Українська соборність : ідея, досвід, проблеми (До 80-річчя Акту злуки 22 січня 1919 р.) : збірник. Київ : ІПіЕНД, 1999. С. 243.

11 Ярославин С. Визвольна боротьба на Західно-Українських землях у 1918-1923 роках. Філадельфія, 1956. С. 30.

${ }^{12}$ Табачник Д. Історія української дипломатії в особах : навч. посібник. Київ : Либідь, 2004. С. 302.
} 
(УПБ) було створене в листопаді-грудні 1918 р. за ініціативою офіцера-галичанина О. Кущака та за сприяння посольства Української Держави. УПБ, за словами його співробітника I. Давидіва, мислилося як: “головний інформаційно-пропагандистський осередок на Європу, централя для постачання вісток, інформацій, матеріалів для всіх інших українських пресових бюро..."13. До вересня 1919 р. УПБ у Відні фінансувалося урядом ЗУНР - ЗОУНР, а з припиненням цієї фінансової допомоги продовжувало діяти на особисті кошти своїх співробітників. Фактично УПБ було головною інформаційною установою галицької республіки за кордоном.

Уряд ЗУНР також був зацікавлений у дружніх взаєминах з Прагою. На думку українського керівництва, саме Чехословаччина (ЧСР) з їі зв'язками на Заході могла б відкрити вільний доступ у Європу і вирішити східногалицьку справу на користь українців. Державний Секретаріат сподівався дістати від ЧСР зброю та військове спорядження, промислові вироби та вугілля. Так, у січні 1919 р. Г. Сидоренко і В. Панейко, зупинившись у Празі по дорозі на Паризьку конференцію, в інтерв'ю з місцевими журналістами, як повідомляла газета Република 11 лютого 1919 р., говорили, крім вище згаданих аргументів, про 100 тис. чехів на Волині і про те, що між Україною і ЧСР немає територіальних непорозумінь, хоча останнє не відповідало дійсності.

У грудні 1918 р. голова УНРади ЗУНР Є. Петрушевич дорогою з Відня до Станіславова зустрівся 3 Т. Масариком. Президент ЧСР пообіцяв підтримати галицьку справу на Паризькій конференції, а Є. Петрушевич призначив до Праги дипломатичного представника ЗУНР професора С. Смаль-Стоцького. Хоча ЧСР офіційно не визнала уряду ЗУНР, вона не визнала і претензій Польщі на Східну Галичину. Т. Масарик вважав, що Східна Галичина має право з'єднатися 3 іншими українськими землями і стати складовою частиною майбутньої Російської демократичної федерації. Коли на початку січня 1919 р. С. Смаль-Стоцький зустрівся з К. Крамаржем, чехословацький прем'єр прямо заявив, що ніякої Західноукраїнської республіки він не визнає, галицькому представництву не дозволить виконувати свої функції навіть напівофіційно ${ }^{14}$.

Важливу роль у переорієнтації східної політики ЧСР відіграв економічний фактор. Свідченням цього була, зокрема проведена Т. Масариком конференція про об'єднання народів від Балтійського до Чорного моря, куди входила й Україна. Враховуючи складне економічне становище новоутворених слов'янських держав, чеські політичні кола застановилися над планами поєднання економіки України й Чехословаччини у “великий господарський союз” для перемоги у світовій конкурентній боротьбі ${ }^{15}$.

Президент ЧСР Т. Масарик, який очолював ліберально-центристське політичне угрупування, висловив прихильність до українського руху і дав дозвіл на в'їзд до Праги дипломатичної місії УНР на чолі з М. Славинським. Внаслідок об'єднання УНР і ЗУНР було вирішено, що подвійність українських дипломатичних представництв допускалися лише в окремих випадках. Для забезпечення інтересів ЗОУНР у кожній місії гарантувалося місце галичанину. I уряд ЗОУНР призначив до складу місії УНР А. Вітошинського, який згодом став її першим секретарем. Водночас у Празі лишався С. Смаль-Стоцький. Між Прагою і Станіславом було налагоджено жвавий обмін кур'єрами та залізничний зв'язок. У лютому 1919 р. до Праги прибув спеціальний посол ЗОУНР Л. Цегельський, велися переговори у справі товарообміну.

У квітні 1919 р. уряди ЧСР і ЗУНР уклали торговельну угоду, за якою Чехословаччина в обмін на промислові товари і зброю отримувала 9 тис. цистерн бориславської нафти. Незважаючи на економічну співпрацю, чехословацька дипломатія у своїй політиці щодо УНР і $3 О$ УНР була обережною і зважала на Антанту. Вимога приєднання Закарпаття була у терито-

\footnotetext{
${ }^{13}$ Веденєєв Д. 3 історії міжнародно-інформаційної діяльності ЗУНР-3ОУНР. Украӥна : культурна спадщиина, національна свідомість, державність. Західно-Українська Народна Республіка. Вип. 6. Львів : Інститут українознавства ім. І. Крип'якевича НАН України, 2000. С. 275.

${ }^{14}$ Павлюк О. Українсько-чехословацька конфедерація (з історії взаємин України і ЧСР в 1917-1921рр.). Київська старовина. 1999. № 1. С. 68.

${ }^{15}$ Нагорняк М. Українське питання в зовнішньополітичній доктрині Т.Г. Масарика. Украӥна : культурна спадщина, наиіональна свідомість, державність. Західно-Українська Народна Республіка. Вип. 6. Львів : Інститут українознавства ім. І. Крип'якевича НАН України, 2000. С. 278.
} 
ріальній програмі Т. Масарика, яка обгрунтовувалася “бажанням населення” звільнитися від Угорщини, але “всенародні збори угорських українців" в Хусті 21 січня 1919 р. заявили про об'єднання з Україною ${ }^{16}$. Галицькі війська у січні 1919 р. силою зброї прагнули поширити українську владу за Карпати, наступаючи у напрямку Мукачева і Сигіта. Але українські війська зазнали поразки від угорців, і чехословацька армія вже у лютому окупувала Закарпаття. Уряд ЗУНР довго не міг визначити своє офіційне ставлення до чехословацької акції, але продовжував підтримувати український рух на Закарпатті.

Прагу відвідували українські делегації. Першим 27 травня 1919 р. приїхав представник уряду ЗОУНР Т. Окуневський, який зустрівся з Т. Масариком та іншими посадовими особами ЧСР. Незабаром на доручення Держсекретаріату ЗОУНР прибула друга делегація (М. Здерковський, С. Баран, Т. Рожанковський) для “нав'язання тісного політичного зв'язку” між ЗОУНР і ЧСР. Вже обговорювались конкретні пропозиції щодо укладення політичного і військового союзу. 2 червня до Праги приїхали міністр закордонних справ УНР В. Темницький і держсекретар ЗОУНР О. Бурачинський. Т. Масарик ще раз твердо заявив, що без дозволу Антанти Прага нічого зробити не може, а чехи самі потребують військової допомоги ${ }^{17}$.

Так усі спроби українських урядів укласти з ЧСР конфедеративний союз не зустріли відгуку у Празі. Політика ЧСР відрізнялася прагматизмом і диктувалася тактичними міркуваннями. У своїй східній політиці офіційна Прага передусім зважала на позицію Антанти.

Великі надії у проблемі міжнародної ізоляції уряд ЗУНР покладав на ще одного західного сусіда - Угорщину. Відносини між ЗУНР і Угорщиною були закладені наприкінці грудня 1918 р., коли Є. Петрушевич відвідав Будапешт, де відбулися його зустрічі з головою уряду М. Карої та міністром у національних справах О. Ясі. Дещо раніше уряд ЗУНР ухвалив рішення “ввійти в переговори з Будапештом в цілі набуття там же потрібної кількості амуніції”. Угорщина була однією 3 небагатьох країн, яка дозволила діяльність представникові уряду ЗУНР сотнику Я. Біберовичу ${ }^{18}$.

Угорська сторона (М. Карої, Ш. Гарбаї, Б. Кун) наполягали у 1919 р. на офіційному визнанні Закарпаття у складі Угорської республіки на правах проголошеної 21 грудня 1918 р. автономії, тоді як українська сторона проводила свою лінію: якщо русини висловляться за прилучення краю до України, то вона перечити не буде. Як відомо, за рішенням Антанти 8 травня 1919 р. Закарпатська Україна, незважаючи на те, що в ній проживало 68\% русинів, $19 \%$ угорців і лише 3-4\% чехів та словаків, потрапила до складу Чехословаччини, що й зафіксував Тріанонський мирний договір від 4 червня 1920 р. ${ }^{19}$. Незважаючи на нерозв'язаність проблеми Закарпаття, Угорщина у 1918-1919 рр. поставилась до УНР та ЗУНР як до своїх найважливіших союзників, українське питання вперше стало одним із найважливіших для зовнішньої політики Угорщини.

У першій половині лютого 1919 р. до Станіслава приїхав представник міністерства торгівлі і промисловості Угорщини М. Пінтер, а наприкінці місяця до Будапешту прибула зунрівська торгівельна місія (С. Вітик, М. Здерковський, В. Дутка). Переговори закінчилися укладенням договорів про залізничне, поштове, телеграфне і телефонне сполучення, про дозвіл перевезення товарів із Заходу та про товарообмін. Галицьке представництво було чи не єдиним, яке лишилося в Угорщині після приходу до влади комуністичного уряду Ш. Гарбаї. Проте, коли міністр закордонних справ радянської Угорщини Бела Кун неофіційно запропонував Я. Біберовичу посередництво між урядами ЗУНР і радянської Росії, Держсекретаріат більшістю голосів цю пропозицію відхилив. Уряд ЗУНР не відгукнувся і на заклик угорського військового

\footnotetext{
${ }^{16}$ Павлюк О. Українсько-чехословацька конфедерація (з історії взаємин України і ЧСР в 1917-1921рp.). Київська старовина. 1999. № 1. С. 70.

${ }_{17}^{17}$ Віднянський С. Українське питання в зовнішньополітичних концепціях Чехословаччини (19181989 рр.). Украӥнський історичний журнал. 1997. № 1. С. 48.

${ }^{18}$ Павлюк О. ЗУНР і політика Угорщини. Міжнар. наук. конф., присвяч. 75-річ. ЗУНР. 1-3 лист. 1993 р. : матеріали. Івано-Франківськ, 1993. С. 88.

${ }^{19}$ Держалюк М., Віднянський С., Коваль В., Сергійчук В., Мартинов А. Україна в зарубіжних доктринах та стратегіях ХХ століття. Політична думка. 1996. № 1. С. 65.
} 
командування наприкінці квітня допомогти у боротьбі проти інтервенції Румунії. Із втратою ЗУНР своєї державної території інтерес угорських властей до Східної Галичини значно ослаб, і взаємини між двома урядами поступово стали прохолодними. Функції Я. Біберовича звелися практично до консульської місії.

Щодо Румунії, то східногалицький уряд, незважаючи на окупацію румунськими військами Північної Буковини, обмежився дипломатичними протестами і заявами про невизнання анексії. Станіслав прагнув підтримувати нейтральні стосунки з Бухарестом. Тому 20 грудня 1918 р. Держсекретаріат ухвалив рішення не проводити мобілізацію “в цілі виступу оружно проти Румунії... із жаданням таких самих запорук із сторони Румунії,20.

Наприкінці березня 1919 р. Бухарест відвідала делегація ЗУНР на чолі з С. Витвицьким, яка висловила думку, що приналежність української Буковини має вирішити Паризька конференція. Румунські політичні кола свою зовнішньополітичну діяльність спрямовували на захоплення ряду українських земель. Газета “Народ” 2 березня 1919 р. повідомляла: “Тепер жадає вже Румун цілої Буковини, Бессарабії, Семигороду, Добруджі і Банату. Румуни не можуть дати собі ради з большевизмом, і жадають, щоб висадились війська коаліції”.

У травні, коли Румунія підтримала польський наступ у Східній Галичині і окупували галицьке Покуття, Держсекретаріат дав наказ своїм військам у Коломиї не чинити збройного опору. Така позиція уряду ЗУНР пояснювалася як відсутністю сил для боротьби з румунами в умовах загального польського наступу, так і менталітетом українського суспільства Галичини, яке було готове терпіти краще румунську окупацію, ніж владу поляків.

Вагоме місце у становленні дипломатичної служби ЗУНР займав Ватикан. Проблеми українців греко-католиків в Галичині, їх змагання за незалежність, а пізніше й за справедливе вирішення "українського питання" були в колі зацікавлень Римської курії, особисто папи Бенедикта XV (1914-1922) і апостольського нунція в Польщі Ахілла Ратті ${ }^{21}$.

Зокрема, 27 грудня 1918 р. папа Бенедикт XV звернувся через посередництво апостольського візитатора А. Ратті до високих церковних достойників воюючих сторін (Ю. Більческі і А. Шептицького) 3 проханням посприяти припиненню братовбивчої війни і встановленню миру. Митрополит А. Шептицький рішуче обстоював національні права свого народу, закликав Святого Отця відверто стати на бік галицьких українців. У листі від 24 січня 1919 р. Галицький пастир закликав папу Бенедикта XV “вивести справедливий вирок” у східногалицькому питанні, стоячи на цілком самостійній, незалежній позиції ${ }^{22}$.

До розв'язання проблем в Галичині безпосереднє відношення мало встановлення дипломатичних стосунків між Ватиканом і Українською Народною Республікою, до складу якої на той час формально входила ЗУНР. Виконуючи свою дипломатичну місію, М. Тишкевич неодноразово зустрічався з папою та державним секретарем кардиналом Гаспаррі в справах українського населення Галичини. Він, зокрема, висловив протест проти наступу польської армії генерала Галлера та проти арештів українських католицьких священиків. Наступник графа М. Тишкевича на посаді посла УНР в Апостольській столиці - о. Франц Ксаверій Бонн також виявив зацікавлення ситуацією в Галичині, про що свідчить його офіційний меморандум. Наслідком української дипломатичної діяльності у Ватикані була щедра матеріальна допомога від Конгрегації для Східних церков, а саме; “40 тисяч лір на поміч переслідуваним духовним особам Галичини, крім того, Ватикан допоміг Україні грішми і ліками на суму 100 тисяч лір",23.

Папським візитатором в Україні був призначений о. Дж. Дженоккі. Місія Дженоккі мала охоплювати терени всієї УНР і з особливим дорученням вияснити ситуацію в Галичині. Однак ні в національному декреті о. Дженоккі, ні в інструкціях від папського нунція в Польщі про це немає мови. Як бачимо, офіційне обговорення проблем Галичини або хоча б згадка про неї в

\footnotetext{
${ }^{20}$ Кройтор В. Проблема Покуття у відносинах між Румунією і ЗУНР. Галичина. 2001. № 5-6. С. 231.

${ }^{21}$ Гентош Л. Ватікан і українське питання в Галичині (1918-1923рр.). Міжнар. наук. конф., присвяч. 75 річ. ЗУНР. 1-3 лист. 1993 р. : матеріали. Івано-Франківськ, 1993. С. 87.

${ }_{22}^{22}$ Цвенгрош Г. Митрополит на сторожі держави. Літопис Червоної Калини. 1994. № 1-3. С. 4.

${ }^{23}$ Нагаєвський І. Історія української держави двадцятого століття. Київ : Український письменник, 1994. C. 355 .
} 
дипломатичних документах Римської курії були все ще не бажаними. Ставлення Апостольської столиці до питання державно-правового статусу Східної Галичини було органічно пов'язане 3 виробленням засад місійної діяльності Ватикану на Сході Європи з метою привернення до єдності з Римським Апостольським престолом православного населення колишньої Російської імперії. Ватикан хоч і ставився прихильно до українського населення та надавав підтримку діяльності Греко-Католицької Церкви, був змушений брати до уваги глобальні зовнішньополітичні зміни, які відбувалися в Східноєвропейському регіоні, що було життєвою необхідністю для Римського престолу в епоху краху багатонаціональних імперій, постання на карті світу нових національних державних утворень та в час невизначеності державно-правового та міжнародного статусу самого Ватикану.

Одним з основних аспектів зовнішньополітичної діяльності ЗУНР був вихід 3 міжнародної ізоляції, що означало здобуття прихильності країн Антанти. Вже 8 листопада 1918 р. доктор Кость Левицький повідомив Великобританію та США про існування нової держави на Сході Європи. Оскільки прямих контактів із цими країнами у західноукраїнської держави не існувало, це повідомлення було зроблено через англійське й американське посольство у Швейцарії й Швеції ${ }^{24}$.

У листі на 14 сторінках, адресованому президентові Вільсону й британському прем'єрміністру, містилася чітка інформація про виникнення нової держави, початок українськопольського конфлікту у регіоні, обгрунтовувалися права українців на створення своєї держави. Лист однозначно відкинув посягання поляків на Східну Галичину як безпідставні ${ }^{25}$.

Як відзначав Т. Гунчак, єдиним винятком в “антиукраїнському хорі” західних держав, була Великобританія. На той час радником британського міністерства закордонних справ Галичини й референтом розвідки 3 польських питань був сер Люїс Намієр, пізніше відомий історик. Він походив з єврейської родини із Заліщик, і дитинство, проведене в українському середовищі, а згодом навчання у Львівському університеті залишили в його пам'яті теплі спогади. Тому, опинившись у впливовій позиції у Форейн Офіс, Намієр переконував англійців підтримати українську справу ${ }^{26}$. Вже 8 листопада британський уряд скерував Польському Національному Комітетові ноту, в якій висловив невдоволення воєнними діями поляків у Східній Галичині і спробою силовими методами вирішити проблему краю перед тим, як іiі мала розглянути Паризька мирна конференція. Слід додати, що англійські представники у Європі лорд В. Кілмарнок у Копенгагені та військовий аташе підполковник Г. Вейд теж притримувались думки, яку повідомили у Лондоні, що Східна Галичина повинна належати українцям ${ }^{27}$.

Представником ЗУНР у Лондоні був Степан Томашівський, який твердив про невизначеність Лондону, адже Англія для підтримання балансу сил у Європі розглядала варіанти приєднання Східної Галичини до України, Росії і навіть Чехословаччини.

28 січня 1919 р. уряд Директорії прийняв рішення "Про вислання надзвичайної Дипломатичної місії до Англії та асигнування на іï утримання 575500 крб. протягом чотирьох місяців”. Після злуки 22 січня 1919 р. уряди ЗОУНР та УНР частково узгоджували принципові зовнішньополітичні позиції, незважаючи на окремі розбіжності між ними.

Українську дипломатичну місію до Лондона очолив М. Стаховський, а до складу увійшли М. Меленевський та С. Шафаренко, а також 6 службовців. Члени місій вручили міністру закордонних справ листа 3 протестом проти польської агресії в Галичині. У Лондоні українська місія не одержала жодної аудієнції ані з А. Бальфуром, ані з його заступниками. Єдиними офіційними особами міністерства закордонних справ, що зустрічалися з нею були Р. Ліпер та Дж. Грегорі - секретар Форейн Офісу, відповідальний за "російське питання". Перебіг зустрічі свідчив про відсутність упередженого ставлення до українців, за винятком деяких

\footnotetext{
${ }^{24}$ Нариси з історії дипломатії України. Київ : Альтернативи, 2001. С. 360.

25 Довган Ю. Участь Великобританії у вирішенні польсько-українського конфлікту в Галичині у 1918 1919 рр. Вісник Прикарпатського університету. Історія. Вип. VII. 2003. С. 154.

${ }^{26}$ Гунчак Т. Україна: перша половина ХХ століття: нариси політичної історії. Київ : Либідь, 1993. С. 162.

${ }^{27}$ Тищик Б. Західно-Українська Народна Республіка (1918-1923). Історія держави і права. Львів : Тріада плюс, 2004. С. 268.
} 
62

питань, що торкалися безпосередньо Росії. Отже, британці перебували під значним впливом російських політичних чинників, які виношували ідею відновлення “сдиної і неподільної Росії”.

При місії було утворене пресове бюро зі штабом співробітників, адже серед першочергових завдань української місії було протистояння російській пропаганді. Адже українське питання в політиці держав Антанти становило частину “російського питання" стосовно Наддніпрянщини та частину “польського питання” щодо Східної Галичини, яка стала предметом не лише польської агресії, але й активної дипломатичної діяльності. Українські представництва за кордоном стали для урядів Антанти, радше, додатковим джерелом інформації про Україну, ніж інструментом встановлення повноцінних взаємин на державному рівні.

Невизначеною щодо галичан кілька місяців була позиція США, лідери якої врешті-решт відхилили варіант утворення ЗУНР. На сході європейського континенту віддавали перевагу федеративним розв'язкам, і це, на думку Вашингтона, мало забезпечити право окремих націй на самовизначення та водночас запобігти балканізації Центрально-Східної Європи та утворення малих нежиттєздатних держав ${ }^{28}$. Щоправда, навесні 1918 р. американський експерт 3 польського питання професор Р. Лорд ще говорив про доцільність відокремлення Східної Галичини: приєднання її до Великої України з кордоном по Сяну або ж до Польщі на правах автономії. На відміну від Франції та Великобританії, які вклали великий капітал у прикарпатський нафтовий басейн, США не виявляли зацікавлення економічним аспектом східногалицької проблеми і будували свою політику щодо ЗУНР, керуючись геостратегічними і національними інтересами $^{29}$.

Американські лідери ставили на перше місце не правовий, а політичний аспект, базований на такому правилі Верховного Суду США: "Хто є сувереном де-юре чи де-факто над територією, це ж не правове, а політичне питання". Навіть у програмних заявах В. Вільсона, сповнених прихильності до національного самовизначення народів “українському питанню окремого місця не знайшлося". В. Вільсон не хотів ускладнювати політичний вибір для Америки. Існували побоювання, що неточно обраний пріоритет призведе до небажаного конфлікту 3 Росією $^{30}$.

10 січня 1919 р. була прийнята постанова "Про вислання Надзвичайної Дипломатичної Місії до Північно-американських Сполучених Держав та про асигнування 1471400 крб. на утримання іiї протягом 6 місяців”. Було також визначено чисельність дипломатичної місії в кількості 13 осіб: голова місії - 1, радники - 3, секретар - 1, заступник секретаря - 1, аташе - 3, урядовці - 4. Проте американський уряд дав дозвіл на в'їзд лише голові і секретареві місії, та й то тільки після кількамісячного зволікання. Зрештою, 1 серпня 1919 р. українські дипломати на чолі з Ю. Бачинським прибули до Вашингтона, щоправда як приватні особи, і звернулися 3 листом до держсекретаря Р. Лансінга, який у відповідь заявив: “Уряд і народ з живим інтересом ставляться до добробуту людей в усіх частинах Росії, включно в Україні. Проте США не визнають ані незалежності України, ані жодного уряду, який тепер там при владі, а тому не готові прийняти представників українського уряду"31. Місія так і не змогла вплинути на позицію офіційного Вашингтона й американського політичного істеблішменту та схилити їх до визнання і підтримки української незалежності.

Опинившись 3 квітня 1919 р. в еміграції, уряд ЗУНР у своїй зовнішній політиці почав робити більший акцент на економічне зацікавлення великих держав природними ресурсами Східної Галичини. Так, Л. Цегельський вступив у неофіційні переговори з представниками окремих американських і канадських компаній, пропонуючи концесії у Східній Галичині в обмін на політичну та фінансову (надання кредитів) підтримку уряду ЗУНР. У 1920 р. професор

\footnotetext{
${ }^{28}$ Павлюк О. Боротьба України за незалежність і політика США (1917-1923). Київ : Вид. дім “КМ Асаdemia", 1996. C. 46.

${ }^{29}$ Литвин М. ЗУНР на геополітичній карті Центрально-Східної Європи. Україна : культурна спадщина, наиіональна свідомість, державність. Західно-Українська Народна Республіка. Вип. 6. Львів, 2000. С. 209.

${ }^{30}$ Несук М., Репринцев В., Камінський $€$. Україна у зарубіжних доктринах та стратегіях XX століття.

Політична думка. 1995. № 2-3. С. 63.

${ }^{31}$ Павлюк О. Три місії до Вашингтона. Політика і час. 1997. № 1. С. 66.
} 
Іван Боберський заснував Галицьке представництво у Канаді, відкривши українське бюро у Вінніпегу. Він разом з О. Назаруком зайнялися збором коштів для $Є$. Петрушевича, сформували необхідні представництва у Вашингтоні та Оттаві, інформували українську діаспору про діяльність ЗУНР та організували національну оборонну позику у Канаді ${ }^{32}$. У червні Л. Цегельський нарешті переїхав з Нью-Йорка до Вашингтона, де 1 липня 1921 р. відкрив галицьке представництво і активізував свою діяльність у політичному напрямі. Але позиція США - невтручання в європейські справи - лишалася незмінною.

Основним противником визнання ЗУНР і надання ій допомоги була Франція. За твердженням В. Ададурова: “світова війна перетворила Францію у наймогутнішу військово-політичну силу континентальної Свропи, радикальним чином зміцнивши іiї вплив на вирішення актуальних проблем міжнародного життя" ${ }^{33}$. Франція всіма засобами підтримувала Польщу як сильного союзника насамперед проти Німеччини. Як зазначав Ллойд-Джордж, “створення великої Польщі було одним з головних намагань французької військової стратегії”. Прем'єрміністр Франції Ж. Клемансо не приховував, що не може пробачити українцям “ганебного миру у Брест-Литовську". Він вважав, що українську національну ідею підтримує Німеччина, нагадував усім, що Австро-Угорщина та в ії складі галицькі українці воювали проти Антанти, дорікав за союз з Берліном і запрошення німецького і австро-угорського війська на Україну навесні $1918 \mathrm{p.}^{34}$.

Політика Франції випливала ще з їі ставлення до так званих “малих країн”. На міжнародній конференції в Лондоні у грудні 1918 р. прем’єр-міністр Франції Ж. Клемансо заявив, що вирішальним фактором має бути мирна політика: “Ми не зобов'язані визнати одразу

всі малі країни. Висловлюючись простими словами скажу: Нехай вони спочатку дозріють, i коли це відбудеться, ми визнаємо їх" ${ }^{35}$. Взагалі французький уряд розглядав українське питання як частину східноєвропейського і бачив його вирішення лише в загальноросійському контексті.

Політика Німеччини щодо українського питання характеризувалася неоднозначністю. Початок українсько-німецьким відносинам поклали Економічний договір від 23 квітня 1918 р. та Господарча угода від 10 вересня 1918 р. Економічні відносини з Німеччиною стимулювали створення та розвиток зовнішньополітичних відомств. За короткий час Німеччина створила на території Української Держави розгалужену мережу своїх дипломатичних представництв, проте дипломатичний корпус був сформований не досить вдало. Дипломати були слухняними виконавцями волі військових представників. При вирішенні Україною питань міжнародного характеру, Німеччина дуже часто займала двоїсту позицію. Уряд ЗУНР також скерував свою дипломатичну місію до Німеччини. Посольство у Берліні очолив Євген Левицький.

Восени 1919 р. до Югославії було вислано місію на чолі з Г. Микитеєм. У Бразилії дипломатичне представництво очолив П. Карманський, у Відні - О. Колесса. У Женеві було утворено Комітет оборони західноукраїнських земель. Отже, розвинута мережа дипломатичних представництв ЗУНР свідчить про становлення ідеї української державності на міжнародній арені і про прагнення західноукраїнських політиків домогтися повноправного існування ЗУНР через іiї світове визнання. Внутрішньополітичні негаразди зумовлювали не лише обмежене фінансово-економічне, інформаційне і технічне забезпечення зовнішньополітичної служби ЗУНР, а й призводили до розколів та суперечностей серед членів українських місій за кордоном.

Незважаючи на розбіжності “українська політика" урядів держав Антанти не становила окремого елементу зовнішньополітичної концепції, а була лише складовою частиною російського, галицького, румунського чи польського питань. Вона опосередковано займала помітне

\footnotetext{
${ }_{32}^{32}$ Герус О. Перші посланці Українського уряду в Канаді. Літопис Червоної Калини. 1993. № 10-12. С. 64.

${ }_{33}$ Ададуров В. Політика Франції стосовно українсько-польського конфлікту за Східну Галичину в період з листопада 1918 по березень 1919 рр. Україна в минулому. Київ : Львів, 1995. Вип. VII. С. 19.

34 Литвин М. Українсько-польська війна 1918-1919. Львів : Інститут українознавства ім. І. Крип’якевича НАН України ; Інститут Центрально-Східної Свропи, 1998. С. 257.

${ }^{35}$ Кучик О. Міжнародне становище України в 1918-1919 рр. Украӥна : культурна спадщина, наиіональна свідомість, державність. Західно-Украйнська Народна Республіка. Вип. 6. Львів, 2000. С. 249.
} 


\title{
64
}

місце у тогочасній європейській політиці, залишаючись засобом не стільки стратегічним, скільки тактичним.

Таким чином, основним аспектом зовнішньополітичної концепції ЗУНР було становлення дипломатичних представництв 3 метою виходу країни з міжнародної ізоляції, збереження незалежності, територіальної цілісності і здобуття міжнародного визнання. На першому етапі діяльності ЗУНР було утворено зовнішньополітичний апарат й визначено пріоритети зовнішньої політики: об'єднання з УНР; здобуття прихильності країн Антанти; налагодження відносин із найближчими сусідами - Чехо-Словацькою республікою, Угорщиною та Румунією. Уряд ЗУНР вірив у дотримання норм міжнародного права щодо справедливого вирішення східногалицького питання. Цими ідеями визначалося становлення дипломатичної служба ЗУНР через відкриття представництв і посольств у Відні, Празі, Будапешті, Бухаресті, Лондоні, Берліні, Вінніпегу, Оттаві, Вашингтоні та інших містах. Слід зауважити, що дії уряду ЗУНР не завжди були юридично закріплені, не вистачало кваліфікованих політиків, коштів і єдиного чіткого плану дій. Важливим загальнонаціональним здобутком цього періоду було прийняття Акту соборності 22 січня 1919 р., хоча і після цього діяли два закордонні уряди, що було негативною стороною дипломатичної діяльності.

\section{DEVELOPMENT OF THE DIPLOMATIC SERVICE OF THE ZUNR (autumn 1918 - spring 1919)}

\author{
Liubomyra FEDUNYSHYN \\ Burshtyn College of Power Engineering \\ of Ivano-Frankivsk National Technical University of Oil and Gas, \\ Kaluska St, 4, 77111, Burshtyn, Ukraine \\ e-mail: fedunyshyn3@gmail.com
}

\begin{abstract}
Summary
Today in the historical science is growing the interest in a comprehensive study of the activities of the diplomatic service of the ZUNR, which was entrusted with a great responsibility for the implementation and partly formation of the foreign policy of the state. Indeed, the fate of the country depends on the professional and consistent implementation of the strategically correctly chosen foreign policy course, the cadre of the diplomatic service, the forms and methods of its work. In this regard, the actual task is to examine objectively the achievements and miscalculations of the formation of the diplomatic service of the ZUNR, to take into account the positive and negative factors of the activity of the Galician republic, which was at the crossroads of geostrategic interests of the great states in Central and Eastern Europe.

The Galician leadership came to be in the actual international isolation. The one-side orientation towards Austria-Hungary and Germany during World War I meant a complete lack of ties with the governments of the Entente states and the United States. The "Ukrainian policy" of the governments of the Entente states did not form a separate element of the foreign policy concept, but was only an integral part of the Russian, Galician, Romanian or Polish issues. It indirectly occupied a prominent place in European politics of the time, remaining more tactical than strategic means.

The actions of the ZUNR in the international arena have not always been legally secured; there was a lack of qualified politicians, funds and a single clear plan of action. Internal political troubles caused not only the limited financial economic, informational and technical support of the foreign service of the ZUNR, but also led to splits and controversies among members of the Ukrainian missions abroad.

Since its inception, the territory of the ZUNR has become the object of encroachment and military aggression by the neighbouring countries. The ZUNR government believed in compliance with the norms of the international law for a fair solution to the East-Galician issue. These ideas determined the establishment of the ZUNR diplomatic service through the opening of representations and embassies.

In the article, we investigate the process of settling the diplomatic service of West Ukrainian People's Republic, peculiarities and problems in operation of international representative offices and missions. It has been mentioned that an important task was formation of foreign policy apparatus and determination of foreign policy priorities: union with the Ukrainian People's Republic, obtaining benevolence of the Entente countries, setting up relations with Czech-Slovak Republic, Hungary, Romania and other countries with aim of preservation of independence, territorial integrity and obtaining international recognition. The author elucidates the
\end{abstract}


facts on opening the representations and embassies in Venna, Prague, Budapest, Bucharest, London, Berlin, Winnipeg, Ottawa, Washington and other cities.

Keywords: West Ukrainian People's Republic, diplomatic service, foreign mission, representation, international activity, ambassador, delegation, foreign policy.

\section{REFERENCES}

Adadurov V. Polityka Frantsii stosovno ukrainsko-polskoho konfliktu za Skhidnu Halychynu v period z lystopada 1918 po berezen 1919 rr. Ukraina v mynulomu. Kyiv ; Lviv, 1995. Vyp. VII. S. 18-32. [in Ukrainian]. Derzhaliuk M., Vidnianskyi S., Koval V., Serhiichuk V., Martynov A. Ukraina v zarubizhnykh doktrynakh ta stratehiiakh XX stolittia. Politychna dumka. 1996. № 1. S. 64-82. [in Ukrainian].

Dovhan Yu. Uchast Velykobrytanii u vyrishenni polsko-ukrainskoho konfliktu v Halychyni u 1918-

1919 rr. Visnyk Prykarpatskoho universytetu. Istoriia. Vyp. VII. 2003. S. 154-163. [in Ukrainian].

Hentosh L. Vatikan i ukrainske pytannia v Halychyni (1918-1923 rr.). Mizhnar. nauk. konf., prysviach.

75-rich. ZUNR. 1-3 lyst. 1993 r. : materialy. Ivano-Frankivsk, 1993. S. 86-88. [in Ukrainian].

Herus O. Pershi poslantsi Ukrainskoho uriadu v Kanadi. Litopys Chervonoi Kalyny. 1993. № 10-12.

S. 64-65. [in Ukrainian].

Hunchak T. Ukraina: persha polovyna XX stolittia : narysy politychnoi istorii. Kyiv : Lybid, 1993.

288 s. [in Ukrainian].

Kalakura Ya., Panchuk A. Novitnia istoriohrafiia Zluky UNR ta ZUNR. Ukrainska sobornist : ideia, dosvid, problemy (Do 80-richchia Aktu zluky 22 sichnia 1919 r.) : zbirnyk. Kyiv : IPiEND, 1999. S. $234-242$. [in Ukrainian].

Karpenko O. Osnovni napriamy zovnishnoi polityky Zakhidno-Ukrainskoi Narodnoi Respubliky. Ukraina : kulturna spadshchyna, natsionalna svidomist, derzhavnist. Zakhidno-Ukrainska Narodna Respublika. Lviv, 2000. Vyp. 6. S. 230-233. [in Ukrainian].

Konstytutsiini akty Ukrainy 1917-1920: Nevidomi konstytutsii Ukrainy. Kyiv : Filos. i sotsiol. dumka, 1996. 272 s. [in Ukrainian].

Kroitor V. Problema Pokuttia u vidnosynakh mizh Rumuniieiu i ZUNR. Halychyna. 2001. № 5-6. S. 231-234. [in Ukrainian].

Kuchyk O. Mizhnarodne stanovyshche Ukrainy v 1918-1919 rr. Ukraina : kulturna spadshchyna, natsionalna svidomist, derzhavnist. Zakhidno-Ukrainska Narodna Respublika. Vyp. 6. Lviv : Instytut ukrainoznavstva im. I. Krypiakevycha NAN Ukrainy, 2000. S. 248-251. [in Ukrainian].

Lytvyn M. Ukrainsko-polska viina 1918-1919. Lviv : Instytut ukrainoznavstva im. I. Krypiakevycha NAN Ukrainy; Instytut Tsentralno-Skhidnoi Yevropy, 1998. 488 s. [in Ukrainian].

Lytvyn M. ZUNR na heopolitychnii karti Tsentralno-Skhidnoi Yevropy. Ukraina : kulturna spadshchyna, natsionalna svidomist, derzhavnist. Zakhidno-Ukrainska Narodna Respublika. Vyp. 6. Lviv : Instytut ukrainoznavstva im. I. Krypiakevycha NAN Ukrainy, 2000. S. 208-230. [in Ukrainian].

[in Ukrainian].

Lytvyn M., Naumenko K. Istoriia ZUNR. Lviv : Instytut ukrainoznavstva NAN Ukrainy, 1995. 362 s.

Nahaievskyi I. Istoriia ukrainskoi derzhavy dvadtsiatoho stolittia. Kyiv : Ukrainskyi pysmennyk, 1994. 413 s. [in Ukrainian].

Nahorniak M. Ukrainske pytannia v zovnishnopolitychnii doktryni T. H. Masaryka. Ukraina : kulturna spadshchyna, natsionalna svidomist, derzhavnist. Zakhidno-Ukrainska Narodna Respublika. Vyp. 6. Lviv : Instytut ukrainoznavstva im. I. Krypiakevycha NAN Ukrainy, 2000. S. 277-281. [in Ukrainian].

Narysy z istorii dyplomatii Ukrainy. Kyiv : Alternatyvy, 2001. 739 s. [in Ukrainian].

Nesuk M., Repryntsev V., Kaminskyi Ye. Ukraina u zarubizhnykh doktrynakh ta stratehiiakh XX stolittia. Politychna dumka. 1995. № 2-3. S. 50-69. [in Ukrainian].

Pavliuk O. Borotba Ukrainy za nezalezhnist i polityka SShA (1917-1923). Kyiv : Vyd. dim "KM Academia", 1996. 188 s. [in Ukrainian].

Pavliuk O. Try misii do Vashynhtona. Polityka i chas. 1997. № 1. S. 65-79. [in Ukrainian].

Pavliuk O. Ukrainsko-chekhoslovatska konfederatsiia (z istorii vzaiemyn Ukrainy i ChSR v 1917-

1921 rr.). Kyivska starovyna. 1999. № 1. S. 65-77. [in Ukrainian].

Pavliuk O. Zovnishnia polityka ZUNR. Vsesvit. 1992. № 1-2. S. 176-178. [in Ukrainian].

Pavliuk O. ZUNR i polityka Uhorshchyny. Mizhnar. nauk. konf., prysviach. 75-rich. ZUNR. 1-3 lyst.

1993 r.: materialy. Ivano-Frankivsk, 1993. S. 88-90. [in Ukrainian].

Pavlyshyn O. Obiednannia UNR i ZUNR: polityko-pravovyi aspekt (kinets 1918 r. - persha polovyna

1919 r.). Visnyk Lvivskoho universytetu. Istoriia. 2002. Vyp. 37/1. S. 329-349. [in Ukrainian].

Tabachnyk D. Istoriia ukrainskoi dyplomatii v osobakh : navch. posibnyk. Kyiv : Lybid, 2004. $640 \mathrm{~s}$. [in Ukrainian]. 
66

Ukrainian].

Tsvenhrosh H. Mytropolyt na storozhi derzhavy. Litopys Chervonoi Kalyny. 1994. № 1-3. S. 2-5. [in

Tyshchyk B. Zakhidno-Ukrainska Narodna Respublika (1918-1923). Istoriia derzhavy i prava. Lviv : Triada plius, 2004. 392 s. [in Ukrainian]. Ukrainian].

Ukraina v XX stolitti. Zbirnyk dokumentiv i materialiv. Kyiv : Vyshcha shkola, 2000. 350 s. [in

Vedenieiev D. Ukrainska istoriohrafiia pro prychyny ta naslidky rozryvu Aktu Zluky (zovnishnopolitychnyi aspekt). Ukrainska sobornist : ideia, dosvid, problemy (Do 80-richchia Aktu zluky 22 sichnia 1919 r.) : zbirnyk. Kyiv : IPiEND, 1999. S. 243-253. [in Ukrainian].

Vedenieiev D. Z istorii mizhnarodno-informatsiinoi diialnosti ZUNR-ZOUNR. Ukraina : kulturna spadshchyna, natsionalna svidomist, derzhavnist. Zakhidno-Ukrainska Narodna Respublika. Vyp. 6. Lviv : Instytut ukrainoznavstva im. I. Krypiakevycha NAN Ukrainy, 2000. S. 274-276. [in Ukrainian].

Vidnianskyi S. Ukrainske pytannia v zovnishnopolitychnykh kontseptsiiakh Chekhoslovachchyny (1918-1989 rr.). Ukrainskyi istorychnyi zhurnal. 1997. № 1. S. 43-62. [in Ukrainian].

Yaroslavyn S. Vyzvolna borotba na Zakhidno-Ukrainskykh zemliakh u 1918-1923 rokakh. Filadelfiia, 1956. 184 s. [in Ukrainian].

Zakhidno-Ukrainska Narodna Respublika 1918-1923. Dokumenty i materialy : u 5 t. T. 1 : Lystopadova 1918 r. natsionalno-demokratychna revoliutsiia. Proholoshennia ZUNR / ukladachi O. Karpenko, K. Mytsan. Ivano-Frankivsk : Lileia-NV, 2001. 584 s. [in Ukrainian].

Zakhidno-Ukrainska Narodna Respublika 1918-1923. Dokumenty i materialy : u 5 t. T. 2 : Derzhavotvorchi y administratyvno-orhanizatsiini protsesy / ukladachi O. Karpenko, K. Mytsan. IvanoFrankivsk : Lileia-NV, 2003. 712 s. [in Ukrainian]. 